Agro-Science Journal of Tropical Agriculture, Food, Environment and Extension Volume 15 Number 3 (September 2016) pp. 13 - 17

ISSN 1119-7455

\title{
DETERMINANTS OF TRAINING NEEDS OF EXTENSION PERSONNEL OF AGRICULTURAL DEVELOPMENT PROGRAMME (ADP) EKITI STATE, NIGERIA
}

\author{
Kolawole, E.A., Isitor*, S.U. and Owolabi, A.O. \\ Department of Agricultural Economics \& Extension, Landmark University Omu Aran, Nigeria \\ *Corresponding author's email: uisitor@hotmail.com
}

\begin{abstract}
The dynamics experienced in agricultural practice has put extension service delivery on a new platform that requires regular updating of the extension staff knowledge for new competences, to meet the changing needs of the clientele they serve. This study therefore sought to determine the training needs of extension personnel of Agricultural Development Programme (ADP) in Ekiti State of Nigeria. The population of the study was all extension personnel in the three agricultural zones of the Ekiti State ADP. Random sampling technique was used to select 60 extension personnel from a total of 65 extension personnel from the zones to which questionnaire were administered; however, only 51 questionnaires were returned which were analysed for this study. The mean age of the extension personnel was 44 years with about $63 \%$ within the age range of 41-50 years. About $76.5 \%$ of the extension workers had higher national diploma (HND). Forty seven percent of the extension personnel had work experience between 11 and 20 years; about 33\% of them had work experience between 1 and 10 years while $19.6 \%$ had above 20 years experience at work. The results of the chi square analysis show that factors such as sex $\left(X^{2}=8.24, p<0.5\right)$, educational level $\left(X^{2}=6.49 ; p<0.05\right)$, years of work experience of the extension personnel $\left(X^{2}=11.58, p<0.5\right)$ and attendance of in-service training $\left(X^{2}=6.32 ; p<0.10\right)$ were significant determinants of their training needs.
\end{abstract}

Key words: Agricultural Extension personnel, extension services, training needs, Ekiti State ADP

\section{INTRODUCTION}

Agriculture is the hub on which the economy of most African countries revolves. It holds a dominant position in job creation and livelihood for a major part of the society, contributes to gross domestic product and essential for creating value and wealth (Chuan-Pole and Angwafo, 2011; NEPAD, 2013). Realizing this importance therefore, governments of most developing countries have made concerted efforts to augment agricultural production and productivity through various intervention initiatives, projects and production technology advanced by well-organized basic and applied research. However, it is important to note that it is the accessibility and adoption of these findings by farmers via an effective agricultural extension platform that will guarantee the increase in production.

In recent times, agricultural practice has increasingly become dynamic, borne out of the introduction of new research findings, paradigm shift in the extension service delivery approaches that emphasize farmers' participation in generation of agricultural knowledge; the debilitating impacts of climate change on agriculture and the evolving adaptive and mitigating strategies, and the use of Information Communication Technology (ICT) in agricultural information dissemination has exposed new demands and challenges in extension service delivery (Akpabio et al., 2013). Radhakrishna (1998) submitted that the educational programmes delivered by extension personnel today are more varied than they have ever been and will continue to change to meet the changing needs of the clientele they serve. Thus training and retraining programmes must be enhanced to ensure they meet the needed service delivery capacity posed by the new agricultural trend. Wals and Bawden (2000) opined that fundamental transformation is required in the competencies of multi-functional extension workers to deal with complexity, uncertainty, and conflicting norms, values and interests associated with sustainability if they would be potential facilitators of sustainable agricultural and rural development. Radhakvishna and Thomson (1996) noted that extension personnel particularly require practical learning that provides them with opportunities to share with rural people in a collaborative process that combines scientific technical knowledge with local indigenous knowledge in client-oriented problem solving activities. Therefore, the future success of extension programmes will be determined to a large degree by the ability of the extension 
personnel to do the job and the extent to which they are up-to-date on the essential agricultural subject matter they are to disseminate.

Although the pre-employment training programmes provided excellent subject matter exposure, the re-training programme provide opportunities for newly employed agent to receive training in preparation for assuming assigned roles in their field units and enhance their ability to maximize performance. Consequently, this evolution of a re-engineered extension service made possible through training is sine qua non to putting in place a virile and responsive extension system that relate to the changing agricultural development objectives and goals. Agbamu (2006) opined that training of extension personnel is one of the essential developmental paths to trail to facilitate effective agricultural extension service delivery and a thriving extension service in the $21^{\text {st }}$ century. Areas of training needs for extension personnel include skills to use new communication technology, interpret research findings, develop leadership skills, nurture leadership skills among others. It is thus important to determine the type of professional development activities extension professionals need for effective extension service delivery in the ever-changing agricultural production context, for improved and sustainable agricultural productivity. The specific objectives of the study were to: describe the personal characteristics of the extension personnel; ascertain the extension tasks performed by the extension personnel; ascertain the training needs of the extension personnel; and identify constraints that impedes access to training by extension personnel.

\section{MATERIALS AND METHODS \\ Study Area}

Ekiti State is situated entirely within the tropics. It is located between longitudes $40^{\circ} 51^{\prime}$ and $50^{\circ} 451^{\prime}$ East of the Greenwich meridian and latitudes $70^{\circ} 151^{\prime}$ and $80^{\circ} 51^{\prime}$ north of the Equator. It lies south of Kwara and Kogi States, East of Osun State and bounded by Ondo State in the East and in the South, with a total land Area of $5887.890 \mathrm{sq} \mathrm{km}$. Ekiti State has 16 local government councils. The 2006 population census by the National Population Commission put the population of Ekiti State at 2,384,212 people. The State enjoys a tropical climate with two distinct seasons. These are the rainy season (April - October) and the dry season (November - March). Temperature ranges between $21^{\circ} \mathrm{C}$ and $28^{\circ} \mathrm{C}$ with high humidity. The southwesterly winds and the North East Trade winds blow in the raining and dry (Harmattan) seasons respectively. Tropical forest exists in the south, while guinea savanna predominates in the northern peripheries. Agriculture is the main occupation of the people of Ekiti, and it is the major source of income for many in the state.
Agriculture provides income and employment for more than $75 \%$ of the population of Ekiti State. Some of agricultural produce in the state are: cash crops such as cocoa, oil palm, kolanut, plantain, bananas, cashew, citrus and timber; arable/food crops such as rice, yam, cassava, maize and cowpea. The Ekiti is a sub-group of the Yoruba. They are culturally homogenous and speak a special dialect of Yoruba language known as Ekiti. Ekiti State has three universities, the state owned Ekiti State University, Ado Ekiti, Federal University Oye Ekiti and Afe Babalola University, Ado Ekiti. All these universities have faculties of agriculture which offer great opportunity for training/retraining of extension personnel. Short refresher courses are organized by these to update extension personnel' knowledge in the extension tasks they perform.

Population of the Study and Sampling Procedure Sixty-five extension personnel in the three zones of Ekiti State Agricultural Development Project (EKSADP) form the population of the study. A simple random sampling procedure was used to select 60 extension personnel, 20 from each zone. However, only 51 of the 60 questionnaires administered were returned and used for this study

\section{Instrument for Data Collection}

Questionnaire was the instrument used for data collection, and the instrument was divided into sections, the first section which dwelled on the personal characteristics of the respondents, elicited information on their age, sex, educational status, job experience and in-service training attendance. Educational status was measured as the highest certificate obtained, and work experience as the number of years spent on the job and attendance of in-service training as yes or no. Training needs of extension staff as captured in this study is the competence gap between the present performance and the requirement for optimal performance of identified tasks that can be filled with training. Extension tasks were identified and listed and respondents were asked to indicate extent of training needed using a three-point level of need measurement; highly needed scored 3, needed score 2; and not needed scored 1 . The responses of the extension personnel on a list of possible constraints were measured on a three-point Likert type scale. The response categories were as follows: major constraint $=3$, minor constraint $=2$, not a constraint $=1$. The cutoff point was determined by summing up the assigned scores in the identified categories and divided by 3 as follows; $3+2+1=5 / 3=1.7$. Any constraint that had a mean score of one and above was regarded as serious while any mean score below one was regarded as not being serious. Data were analyzed using descriptive statistics such as frequency counts, percentages, means and standard deviation. 
Chi square analysis was used to test the relationship between some selected socio economic characteristics and training needs of respondents.

\section{RESULTS AND DISCUSSION Personal and Socio-Economic Characteristics of Respondents}

Table 1 shows that the mean age of the respondent is 44 years, hence most of the extension personnel are still young. About $63 \%$ of the respondents fall within the age bracket of 41-50 years. About 24\% of the extension personnel are between 30 and 40 years of age while $1.9 \%$ are below 30 years of age. About $11.8 \%$ of the respondents are within 51-60 years old. This age distribution reveals that majority of the respondents are still in their midage, implying that most of them are still active and can cope with the demand of the job. It is also plausible that since they are still very young they may be more innovative and easily embrace changes dictated by the tides of the modern agricultural practices. They have potentials for training and retraining for improve performance. Training acquired by these extension personnel would be of longer benefit to the extension organization; the impact would be felt for a considerable number of years before the officers' retirement from active service. Knowledge gained and skills acquired must have been passed across to the younger extension personnel through mentorship to ensure sustained gains of the training impact. This is corroborated by the findings of Adisa and Balogun (2012) and Okeowo (2015).

Furthermore, about $78 \%$ of the respondents are males (Table 1). This skewed distribution in the sex of the extension personnel is a reflection of the common staff distribution in the agricultural extension profession. This may be as a result of a wrongly painted mental picture that agriculture is a male domain, or the cultural inclinations in most clime that the women folks should be subservient to men which made it culturally wrong for women to train men who are deemed to be the only noticeable stakeholder in agriculture. This is in line with the findings of Adeola and Ayoade (2011) which reported that ADP extension service is dominated by male. The implication of this is that technology generation and dissemination may be gender skewed, particularly towards the male farmers (Salau and Saingbe, 2008).

It is shown in Table 1 that $98 \%$ of the extension personnel are married while $2 \%$ indicated that they were single. This implies that majority of the extension personnel are better equipped experience wise in family affairs and will be in the best position to fulfill the obligations of not just disseminating improved agricultural innovations to the farmers but offering robust and all-encompassing advisory service to the farm households. It is also shown in table I that $76.5 \%$ of the extension personnel have Higher National Diploma certificate, $13.7 \%$ have Bachelor of Science degree, and 5.9\% have MSc degree while $3.9 \%$ of the respondents have Ordinary National Diploma. This distribution did not only show high literacy level but a high sense of adequate prerequisite professional trainings for better performance. That the bulk of the extension personnel have higher and ordinary diploma in agriculture emphasizes the possession of the needed practical expertise that the demands of their job stipulate. The small percentage of the extension personnel that have Bachelor of Science and Masters of Science degree signifies a culture of continuous improvement and capacity building tendency among them. This educational qualification $\operatorname{mix}$ is healthy for a robust backstopping of the junior extension personnel by their superiors in professional matters.

Forty seven percent of the extension personnel have 11-20 years of work experience, $33.3 \%$ have 1-10 years of professional experience, and $17.9 \%$ have been in the employment of the organization for between 21-30 years while 2\% of the extension personnel have above 30 years of professional experience. The mean value of years of experience was 14.7 years. This distribution shows that all the staff are experienced and can make their wealth of experience bear on the job.

It is also shown in Table 1 that majority of the extension personnel $(88.2 \%)$ have undergone one in-service training or the other since they were hired, however this tempo is not sustained based on the reported myriads of problems to accessing training. while $9.8 \%$ said they never attended any and $2 \%$ did not respond. The majority of them who indicated they have undergone in-service training is an indication of virile training programme in the Ekiti State agricultural development, however this may be just the routine Monthly Technical Review Meeting (MTRM). Nevertheless, it is not yet certain if this training is on a sustainable basis and the scope professionally all encompassing.

Table 1: Socio- economic characteristics of extension personnel

\begin{tabular}{|c|c|c|c|}
\hline Variable & ercentage & Variable & Percentage \\
\hline \multicolumn{2}{|c|}{ Age } & \multicolumn{2}{|c|}{ Educational Level } \\
\hline$>30$ & 2 & OND & 3.9 \\
\hline $30-40$ & 23.5 & HND & 76.5 \\
\hline $41-50$ & 62.8 & $\mathrm{BSc}$ & 13.7 \\
\hline $51-60$ & 11.7 & $\mathrm{MSc}$ & 5.9 \\
\hline \multicolumn{2}{|c|}{ Sex } & \multicolumn{2}{|c|}{ Years of Professional Experience } \\
\hline Male & 78.4 & $1-10$ years & 33.3 \\
\hline \multirow[t]{3}{*}{ Female } & 21.6 & $11-20$ years & 47.1 \\
\hline & & 21-30 years & 17.6 \\
\hline & & $>30$ & 2 \\
\hline \multicolumn{2}{|c|}{ Marital Status } & \multicolumn{2}{|c|}{ Attendance of in-service Training } \\
\hline Single & 2 & Yes & 88.2 \\
\hline \multirow[t]{2}{*}{ Married } & 98 & No & 9.8 \\
\hline & & Non response & 2 \\
\hline
\end{tabular}

Source: Field survey 2016 


\section{Extension Personnel Areas of Training Need}

Table 2 is a run-down of the areas of training needs as perceived by the extension personnel in Ekiti State. Planning for demonstration with a mean value 2.57 ranked highest as a training need of the extension personnel, this is followed by knowledge on food nutrition and home management with a mean value of 2.49 and a standard deviation of 0.10 . These may be because of the fact that the bulk of the extension personnel are male who by gender roles may not be too conversant with the knitty gritty of food, nutrition and home management. Skills and procedures on modern storage methods of crops ranked next with a mean value of 2.43, this may be as a result of recent focus of research searchlight in the this area in a bit to ensure food security and sustained availability of food crops via storage of surpluses at the peak of harvesting period of most crops. Also most of the farmers are subsistent farmers with little to store, and so training focus might have not been directed towards this area in the past due to its level of importance in the context in which they operate. Training in communication skills ranked $4^{\text {th }}$ with a mean value of 2.41. This is expected due to the fact that communicating itself is the hub of the agricultural extension personnel activity. Therefore extension personnel need regular update of his or her communication skills to remain effective in extension service delivery. The introduction of ICT and the introduction of new trends to agricultural extension communication demands communication skills update if extension personnel will retain relevance in the tides of changes brought by the application of these gadgets in extension service delivery. Selection and training of contact farmers, report writing, setting up of farmers' cooperative and script writing all ranked $5^{\text {th }}$ areas of training need. These activities are core areas of extension personnel responsibilities and it is important that they are regularly updated via training to keep them abreast of the demands of the jobs as they are acquainted with development brought on board to ensure that they are in tune with best global practices in agricultural extension service delivery that is also translated by improved farmers productivity. Other areas of training needs include food value chain, animal husbandry, use of audio visual equipment, climate change, SPAT, and REFILLS, which ranked next to one another.

\section{Constraints Faced by Extension Personnel in Meeting Training Needs}

All the eleven constraints listed were reported as serious constraints to meeting the training needs of extension personnel in Ekiti State as presented in Table 3. They are: paucity of fund for training in extension organization $(\mathrm{M}=2.7)$, non-payment of training allowances $(\mathrm{M}=2.6)$, non-availability of equipment and facilities to implement skills acquired
Table 2: Extension personnel areas of training need

\begin{tabular}{lccc}
\hline Training needs & Std.dev & Mean & Rank \\
\hline Planning for demonstration & 0.09 & 2.57 & $1^{\text {st }}$ \\
Selection and training of contact & 0.11 & 2.37 & $5^{\text {th }}$ \\
farmers & & & \\
Agricultural value chain addition & 0.10 & 2.35 & $9^{\text {th }}$ \\
Organizing SPAT & 0.12 & 2.25 & $13^{\text {th }}$ \\
Organization of REFILLS & 0.11 & 2.21 & $14^{\text {th }}$ \\
Report writing and record keeping & 0.11 & 2.37 & $5^{\text {th }}$ \\
Food, nutrition and home & 0.10 & 2.49 & $2^{\text {nd }}$ \\
management & & & \\
Script writing and documentary & 0.11 & 2.37 & $5^{\text {th }}$ \\
preparation & & & \\
Setting up farmers' cooperative & 0.10 & 2.37 & $5^{\text {th }}$ \\
Climate change & 0.11 & 2.27 & $12^{\text {th }}$ \\
Communication skills & 0.11 & 2.41 & $4^{\text {th }}$ \\
Animal husbandry & 0.09 & 2.35 & $9^{\text {th }}$ \\
Modern storage methods & 0.10 & 2.43 & $3^{\text {rd }}$ \\
Use of audio visual and other & 0.11 & 2.33 & $11^{\text {th }}$ \\
ICT equipment & & & \\
\hline Source: Field survey 2016 & & &
\end{tabular}

Source: Field survey 2016

during most of the training $(\mathrm{M}=2.5)$, misappropriation or channeling of fund earmarked for training for a different project $(\mathrm{M}=2.5)$, selection of staff for training not on the basis of merit $(\mathrm{M}=2.4)$, poor awareness of available training opportunities $(\mathrm{M}=2.3)$, administrative bottlenecks in releasing staff for training programme $(\mathrm{M}=2.2)$, poor linkages among extension organizations $(\mathrm{M}=2.2)$, poor perceptions of need for staff training $(\mathrm{M}=2.2)$, pressures of work $(\mathrm{M}=1.9)$ and educational level of extension personnel $(\mathrm{M}=1.8)$.

Most of the identified constraints to meeting training needs of extension personnel revolve around poor funding of the extension organizations. This is manifested in the non-availability of fund to organize in-house training programmes, poor quality of training programme organized, non-payment of staff training allowance especially when the training is organized by an external context, nonprovision of equipment and facilities to implement skills acquired during trainings and biases in selection of those to attend training programmes. Extension organization particularly the ADP has suffered poor funding since the withdrawal of the World Bank assistance. This is worsened by the economic recession currently experienced in the country which has drastically affected funding of government organizations and parastatals.

\section{Relationship of Some Independent Variables} and Training Needs of Extension Personnel

The results of chi square analysis in Table 4 reveal that sex with $X^{2}$ value of 8.2373 was significant at $p$ $<0.05$, educational level with $X^{2}$ value of 6.4967 was significant at $p<0.10$, year of professional experience with $X^{2}$ value of 11.5751 was significant at $p<0.10$ and attendance of in-service trainings with $X^{2}$ value of 6.3191 was significant at $p<0.05$. However, age and marital status of extension agent were not significant determinant factors of training 
Table 3: Constraints to extension personnel access to training

\begin{tabular}{|c|c|c|c|}
\hline Constraint & Std. dev. & Mean & Rank \\
\hline $\begin{array}{l}\text { Paucity of fund in extension } \\
\text { organization }\end{array}$ & 0.09 & 2.7 & $1^{\text {st }}$ \\
\hline $\begin{array}{l}\text { Educational level of extension } \\
\text { personnel }\end{array}$ & 0.10 & 1.8 & $11^{\text {th }}$ \\
\hline $\begin{array}{l}\text { Management's poor perception } \\
\text { of staff training }\end{array}$ & 0.11 & 2.2 & $7^{\text {th }}$ \\
\hline Pressure of work schedules & 0.11 & 1.9 & $10^{\text {th }}$ \\
\hline $\begin{array}{l}\text { Poor awareness of available } \\
\text { training programme }\end{array}$ & 0.11 & 2.3 & $6^{\text {th }}$ \\
\hline $\begin{array}{l}\text { Poor linkages among extension } \\
\text { organizations }\end{array}$ & 0.11 & 2.2 & $7^{\text {th }}$ \\
\hline $\begin{array}{l}\text { Non-payment of training } \\
\text { allowances }\end{array}$ & 0.08 & 2.6 & $2^{\text {nd }}$ \\
\hline $\begin{array}{l}\text { Equipment to implement skills } \\
\text { learnt at training not provided }\end{array}$ & 0.09 & 2.5 & $3 \mathrm{rd}$ \\
\hline $\begin{array}{l}\text { Selection of staff for training not } \\
\text { on merit }\end{array}$ & 0.10 & 2.4 & $5^{\text {th }}$ \\
\hline $\begin{array}{l}\text { Funds for training } \\
\text { misappropriated }\end{array}$ & 0.11 & 2.5 & $3^{\text {rd }}$ \\
\hline $\begin{array}{l}\text { Administrative bottleneck in } \\
\text { releasing staff for training }\end{array}$ & 0.12 & 2.2 & $7^{\text {th }}$ \\
\hline
\end{tabular}

Source: Field survey 2016

Table 4: Relationship of some socioeconomic variables and training needs of extension personnel

\begin{tabular}{lcccc}
\hline Independent Variable & $X^{2}$ & DF & P & Decision \\
\hline Age & 2.2936 & 4 & 0.514 & $\mathrm{NS}$ \\
Sex & 8.2373 & 1 & 0.004 & $\mathrm{~S} *$ \\
Marital status & 0.6056 & 1 & 0.436 & $\mathrm{NS}$ \\
Educational level & 6.4967 & 3 & 0.090 & $\mathrm{~S} * *$ \\
Years of experience & 11.5751 & 3 & 0.072 & $\mathrm{~S}^{* *}$ \\
Attendance of trainings & 6.3191 & 1 & 0.042 & $\mathrm{~S} *$
\end{tabular}

$*=$ significant at $0.05 \% ; * *=$ significant at $1 \%$

needs of extension personnel. The reason for the significant relationship between respondent educational level and areas of training need may not be far-fetched; this may be due to the variation in the extension personnel's educational level and the differences in their areas of specialization, which may not totally prepare them for the tasks assigned to them. Therefore, there may be need for training and re-training to acquire competences not provided for by the pre-employment training acquired by them. The significant relationship between extension personnel' years of professional experience and training needs may be as a result of the changing job status occasioned by staff promotion which may translate to additional and higher responsibilities that need improved skills for better performance and actualizing of the new tasks. Moreover, extension personnel that have been on the job for a considerable number of years may need to be updated to meet up with new extension service demand from the clienteles.

\section{CONCLUSION/RECOMMENDATION}

Extension personnel in the service of the Ekiti State Agricultural Development Programme are mostly male with just very few female. Majority of them are still young and possess required minimum educational background, which are good potentials for on the job training. Most of them have undergone in-service trainings since they were hired. However, this training has not been on a sustained basis, and the bulk may just be the monthly technical review meetings. The extension personnel highly need training in planning of demonstrations, nutrition and home management Skills, modern storage methods and good communication skills. However, access to training is bedeviled by a number of problems, which revolves around poor funding of the extension organization. It is therefore recommended that needed financial and administrative platforms should be put in place to facilitate access to training by these extension personnel for improved extension service delivery.

\section{REFERENCES}

Adeola, R.G. and Ayoade, A.R. (2011). Extension personnel' perception of the information needs of women farmers in Oyo State, Nigeria. Global Journal of Human Social Science, 11 (10), 33-36

Adisa, R.S. and Balogun, K.S. (2012). Analysis of training needs of extension agents on climate change issues in Ekiti State Agricultural Development Project (EKSADP). Nigeria Journal of Agricultural Extension, 16 (2), 24-36

Agbamu, J.U. (2006). Essentials of Agricultural Communication in Nigeria. Ibadan: Mathias Press Limited, pp. $1-11$

Akpabio, I.A., Okon, D.P. and Inyang, E.B. (2007). Constraints affecting ICT utilization by agricultural extension officers in the Niger Delta, Nigeria. Journal of Agricultural Education and Extension, 13 (4), 263-272

Chuhan-Pole, P. and Angwafo, M. (eds.) (2011). Yes Africa Can: Success Stories from a Dynamic Continent. Washington, D.C.: World Bank

NEPAD (2013). Agriculture in Africa: Transformation and Outlook in Annual Trends and Outlook Report, 1-72. New Patnership for Africa Development

Okeowo, T.A. (2015). Analysis of competency and training needs among agricultural extension personnel in Lagos State. International Journal of Forestry and Horticulture, 1 (2), 14-21

Radhakrishna, R.B. (1997). Program evaluation and accountability needs of extension professionals in the $21^{\text {st }}$ Century. Unpublished Report, Clemson University, Clemson, SC

Radhakrishna, R.B. and Thomson, J.S. (1996). Extension agent's use of information sources. Journal of Extension, 34 (1). Available on-line at: www.joe.org

Salau, E.S. and Saingbe, N.G. (2008). Access and utilization of Information and Communication Technologies (ICTs) among agricultural researchers and extension workers in selected institutions in Nasarawa State of Nigeria. PAT, 4 (2), 1-11

Wals, A. and Bawden, R. (2000). Integrating sustainability into agricultural education: Dealing with complexity, uncertainty and diverging worldviews. SOCRATES Thematic Network for Agriculture, Forestry, Aquaculture and the Environment (AFANET), University of Aberdeen, Scotland 